\title{
ETHICS AND SPORTS, ETHICS IN SPORTS, SPORTS ETHICS - ASPECTS OF CONSIDERATION OF DIFFERENT AUTHORS
}

\author{
Ljubica Milanovic ${ }^{1}$, Nebojša Ranđelović ${ }^{2}$, Danijela Živković ${ }^{2}$ and Zvezdan Savić ${ }^{2}$ \\ ${ }^{1}$ Faculty of Physical Education and Sport, East Sarajevo \\ 2 Faculty of Sport and Physical Education, Nis
}

\section{SUMMARY}

Ethics issues are an issue today wherever there is competition for profit. Contemporary registered sport is a social activity and is, therefore, one of the spheres in which the above-mentioned phenomenon is present.

Sports ethics as a term in everyday life is understood as the unwritten rules of behavior of people in sports, and in this sense, it starts from the assumption of fair relations in all spheres of sports. Honesty is one of the basic human values, a characteristic that reflects righteousness, principality, loyalty to commitments, honesty. The opposite of this is lies, deceit, hypocrisy.

Maintaining ethical rules (norms) enhances the moral influence of sport and the responsibility of all participants in the sport for their behavior and, thanks to the immense attractiveness of sport for the youth, it contributes to improving the moral climate among the youth.

Practical research and theoretical work on the conditionality and connection between ethics and sport exist, but they are scarce to some degree.

The paper deals with the phenomenon of sport and its connection with ethics, considering theoretical, research and professional papers, and outlining the essence of individual papers that are important for the study of this issue. They deal with the connection between ethics and sport in a certain way.

Keywords: sport, ethics, sports ethics

Corresponding author

Nebojša Ranđelović

nebojsa@fsfv.ni.ac.rs 


\section{INTRODUCTION}

If we define the physical exercise as a human movement, determined by its form and character, made with a specific goal - to develop and improve certain human, especially physical abilities, it is inevitable to ask a few questions: does this and such a movement enable people to express themselves as beings; whether this movement, as a gracious food, enables something to be learned about the bodily part of the human being; whether such a movement is worth the time spent and whether such a movement allows to harmonize and increase a person's physical, intellectual and other abilities? ${ }^{1}$

Today, physical exercise has become a part of popular culture and enough is already known about it. Another question is how people in general understand the meaning of physical culture. If physical exercise is experienced as a "graceful food" for the human body, then two global tendencies become incomprehensible: on the one hand, the absence of any desire to use it, even occasionally, and, on the other hand, the use of physical exercise not for the good of man, but for good of body cult, sports score cult or profit cult. This results in a certain degradation of sport itself and human society as a whole, viewed from the aspect of certain moral principles and values ${ }^{2}$.

Spiritual and moral stagnation of modern society which, among other aspects of overall life and in the field of sports, produced its reduction to one dimension the dimension of results, behind which stand the concrete material interests of power and popularity, to which everything is subordinated, even the noblest component of sport - the game. In the anthropological sense, man is defined as „a being whose one of the essential properties is playing". The spiritual stagnation of modern man is a consequence of ratiocentrism (and his abandonment of the concept of theocentrism), hopelessness and loss of ethics produced the instrumentalization of the body-spirit complex, and it reduced sports competition to an alienating form of results at all costs. The consequence of all this is that the athletes themselves are the central actors in the competition (either with others or with themselves) become a profitable instrument. Spiritual stagnation has produced an ethical crisis, and left sport and its actors without a human dimension of existence, reducing them to an alienated plane of corporeality and its ruthless and cruel exploitation ${ }^{3}$.

\footnotetext{
${ }^{1}$ Ненад Живановић и др., Теорија физичке културе. (Ниш:Паноптикум, 2010), 54.

2 Ненад Живановић, Апологија физичког вежбања. (Ниш: Паноптикум, 2011), 39.

${ }^{3}$ Ljubiša Despotović, One-dimensional sport spiritual crisis as a cause of degrading sport to a one dimesional phenomenon. Physical education and sport through the centuries 5(2) (2018): 68-77
} 
Problems of ethics are relevant today wherever there is a competitive struggle aimed at making a profit. Modern registered sport is a social activity, and therefore is one of the spheres in which the aforementioned phenomenon is present. One of the basic aspirations of modern sports whose development is related to the renewed Olympic Games was the principle of fair play. If we have in mind ethics in sports and violation of its principles, but also violation of the basic principles of modern Olympic Games, it can probably be concluded that this phenomenon (expressed to a greater extent) relatively recent and is becoming increasingly relevant today. The reason for this is that athletes are increasingly focused on winning in any form during their sports careers, and especially financially, which differs significantly from the original philosophy on which the new Olympic Games and the Olympic movement are based, and with it the overall development of modern sport. Demonstration of this orientation is constantly present in various forms, all the way to bribing referees, taking doping substances and injuring an opponent. The reason for this is the least recognition, and even medals, and much more financial resources that are awarded to the winners, which is why athletes very often lose control, consciously or unconsciously, because they perceived the sport opponent as an enemy that could potentially jeopardize their earnings and livelihood, so as such it should be prevented or defeated at all costs. Such thinking and behavior leads to negligence of ethical norms and leads to disturbances in sports and the creation of negative social relations. That is why when mentioning the association between ethics and sports today (ethics in sport, the ethics of today's sport), people usually think of negative (unethical) phenomena in sports. Most of those who are interested in sports, and especially those who do sports (primarily registered - professional, top sports) have witnessed a number of unethical elements related to sports (doping, corruption, match-fixing, sports trafficking, dominance of certain sports and the same time insufficient investment in those less attractive (less profitable), insults on various grounds (national, religious, gender, etc.) ${ }^{4}$. Also, in recent years, one can witness the suppression of basic fair play principles, ethics, which speaks in favor of the crisis of sports ethics (ethics in sports), and thus the crisis of athletes as subjects in sports.

The term "ethics" (Greek ethos - nature, custom) can be used in two meanings. First of all, it is a system of unwritten rules, norms, which regulate the mutual relations of people or certain social groups. This ethic has a practical meaning and is defined as a fact of social experience. It aims to regulate relationships between people in a variety of situations. In accordance with the achieved development level of society, the meaning of this term is enriched by adding moral categories such as: conscience, meaning of life, compassion, self-sacrifice, etc. The term

\footnotetext{
${ }^{4}$ Morana Brkljačić, Etika i sport. Medicina Fluminensis, 43(3) (2007): 230-233.
} 
"morality" (from the Latin mores - a generally accepted tradition, custom) was first introduced by Cicero, a Roman politician, philosopher and orator. Morality means generally accepted attitudes in society about good and bad, right and wrong, good and evil, as well as the totality of unofficial principles, rules and norms of behavior that result from these attitudes. Morality is adopted by living and educating in a certain social environment. It relies on the consciousness and conscience of the individual who adopts certain unwritten rules and customs that determine the relations of people and relates to the issues of good and evil5. Morality is socio-historically conditioned, so it changes in relation to the historical period, class and differs from social community to social community.

With the development of physical culture, especially sports, norms and rules of international sports have become stronger. The "Sports Manifesto" of the International Council on Physical Education at the United Nations emphasizes the ethical aspect of morality, which is reflected in the fact that sport is a physical activity that has the character of play and struggle, and sports rules must be respected to have a fair play relationship. These rooles were interduced by Pierre de Coubertin and they are related primarily to the Olympics. Based on the extent to which adherence to these principles is present, the question of the ethics of sport is determined. The moral crisis is a phenomenon that is present in every society and whose causes are different (economic, political, etc.). Sports ethics as a concept is understood in everyday life as unwritten rules of behavior of people in sports, and in that sense we start from the assumption of fair relations in all spheres of sports activities. Honesty is therefore one of the basic human values, a characteristic that reflects justice, principle, fidelity to accepted obligations, honesty. The opposite of this is lies, deception, hypocrisy. Athletes are expected (in terms of respecting ethical norms), for example: not to give up performances without justifiable reasons, not to enter into a dispute with the referees, not to stop the game ahead of time even if they are convinced that they are going to lose, not to behave unsportsmanlike towards a teammate or opponent, to pay tribute to the opponent after the lost match. There are similar requirements for coaches who should be an example for all athletes. Preservation of ethical rules (norms) strengthens the moral impact of sports and the responsibility of all participants in sports for their own behavior and, thanks to the great attractiveness of sports for young people, contributes to improving the moral climate among young generations.

Practical research and theoretical considerations on the conditionality and connection between ethics and sports exist, but they do not exist to a large extent. Only some of them will be presented here.

5 Platon. Država. (Beograd; BIGZ, 1997). 


\section{THEORETICAL FRAMEWORK}

The paper discusses the phenomenon of sport and its connection with ethics by considering theoretical, research and professional papers, and summarizing the essence of individual papers that are important for the study of this issue. They treat the association between export ethics in a certain way.

The book written by William John Morgan, Ethics in Sport6 is the first edition of a collection of papers in the field of sports ethics and an important collection of research on this topic. The collection relies on key articles from the field of philosophy of sport, but focuses specifically on ethical topics and not on the philosophy of sport as a whole. It contains five thematic units: fair play, good sports and cheating: victory at what cost, the limits of human existence: the case of increasing performance through drugs, women in sports: gender equality and gender identity, animal in sports: where do we set the moral line? and the social ethics of sport: whether sport is good for society. The second edition from 2007 was supplemented and expanded with thirteen new texts, three of which were previously unpublished, and the thematic units were changed and more precisely defined: the moral foundations of sport. In the second part - Competition and fair play: consideration of victory, cheating and victory at any cost, there are 10 papers, and some of the issues discussed are: the meaning of sports, fair play as respect for the game, honesty as a moral category, victory and superiority, cheating in sports, intentional breaking of rules. The third part is marked as Human Limits: Doping and Genetic Improvement in Sports, with 6 papers, and discusses the use of doping through questions about whether current bans are justified, making winners using genetic technology and the morality of using such technology and genetic engineering athletes. The fourth part - Gender and gender equality in sports has five papers and deals with issues of equality of women's participation in sports and gender discrimination in sports. The fifth part is entitled - Selected content from the social ethics of sport: violence, exploitation, race, viewership and disability has eight papers on various topics (exploitation of student athletes, violence in sports, disability rights in sports and education, sport idolatry, racism). A publication that also deals with this topic in a broader sense is the book Ethics and Sport, which is a collection of works by various authors in this field and makes a significant contribution in the field of sports ethics. The collection presents topics from different social spaces, but also views from different philosophical perspectives. The collection is an attempt to explore the connection between sports ethics and what is sometimes called "mainstream" philosophy, various traditional interpretations of sports ethics (physical exercise

\footnotetext{
6 W. J., Morgan, K. V. Meier, and A. J. Schneider, (eds) Ethics in Sport, Champaign, Illinois: Human Kinetics (2001).
} 
and training). It is divided into four thematic units: the first part (Ethics and sport - the contribution of philosophy) is presented with three works, the second part (Fair play and sports behavior) is also presented with three works, the third part (Ethics, physical education and sports training) is presented with four papers, the fourth part (Contemporary ethical issues in sports) contains five topics.

Mike McNamee ${ }^{7}$ has also published a book entitled The Ethics of Sports: $A$ Reader. The book discusses ethical issues related to participation in sports and the ethical character of sports themselves. The book consists of 65 chapters presented in seven thematic units. The first part, entitled "The Roots of Sports Ethics: Games, Play, Sports", discusses the conceptual foundations of sports ethics. In the second "Fair Contests: Rules, Spoiling and Cheating", the structure based on rules in general are considered. The third part - "Doping, Genetic Modification and the Ethics of Enhancement", describes the ethical problems associated with increasing efficiency under the influence of pharmacology or genetics. The fourth part "Cultures of Equality and Difference: Dis/ability, Gender and Race" discusses issues of disability, racial and gender relations and racial and gender discrimination in sports. Fifth part - "Ethical Development In and Through Sports: Rules, Virtues and Vices" discusses ethical development in and through sport. The sixth part -" Commercialism, corruption, exploitation in sport "is dedicated to commercialization, corruption and exploitation in sport. The seventh part - "Ethics and Adventurous Activity" discusses outdoor events that are the subject of sports ethics. The book discusses the most current topics of sports ethics, which determine our understanding of sports, sports behavior and sports in practice, and which shed light on a wide range of issues in contemporary sports research.

Jan Boxill ${ }^{8}$ in his book Sports Ethics, an Anthology published thirty-five essays addressing a wide range of ethical issues in sport. It is divided into eight chapters of different sizes that deal with the relationship between sports and education, sports personality, competitions, drugs and medicines, violence, gender, race, etc. It relies on the analysis of various authors dealing with sports issues and includes philosophers, psychologists, sociologists, coaches and journalists. This book is important for those who deal with issues of ethics relevant to theory and practice. First part (Sport and Education) contains five topics, the second part (Sport and Sportsmanship) contains five topics, the third part (Sport and Competition) contains four topics, the fourth part (Sport and Drugs) contains three topics, the fifth part (Sport and Violence) contains three topics, the sixth part (Sport and Gender) contains eight topics, the seventh part (Sport and Racial Issues) it is presented by three themes, the eighth part (Sport and Role Models) contains three topics.

\footnotetext{
${ }^{7}$ Mike J. McNamee, The Ethics of Sports: A Reader, London: Routledge (2010)

8 J. Boxill, (ed), Sports Ethics, an Anthology, Blackwell Publishing, Malden (2003)
} 
Right Actions in Sport, Ethics for Contestants ${ }^{9}$ is a classic text that was a key driver in the emergence of ethical issues in sports as one of the dominant topics in the philosophy of sport. The text shapes the structure needed to establish guidelines for moral action in sport. This structure has three elements: establishing a point of view, developing guidelines and specifying goals that are in line with the point of view. The first chapter presents an introduction that identifies the basic problem of playing sports by presenting cases in which there seem to be a number of possible answers. Five illustrative cases have been described: a case of false injury; case of intentional violation; a case of a tennis player's mistake, a case of anabolic steroids, and a case of unequal competition. It is argued that a moral basis is necessary for proper action. The first part of the book (Chapters 1 and 2) identifies the problem of research and shows the structure for establishing guidelines. The second part (chapters 3-7) shows in more detail the moral nature of sports, taking into account the end of sports competitions, win/loss and the quality of the game, rules, relations between opponents and values in sports competitions. The third part (Chapters 8-10) describes a series of guidelines for moral action in sport, the fourth part (Chapters 11 and 12) deals with the problem of the context of application (Chapter 11) and the moral factor, reasons for action and moral maturity (Chapter 12).

Bodin and Sempé10 discuss the connection between ethics and sport in their monograph Ethics and Sport in Europe. This monograph, consisting of two chapters and six topics in the first and eight topics in the second, was the result of the 11th Council of Europe Ministerial Conference on Sport held in Athens on 11 th and $12^{\text {th }}$ December 2008, followed by a meeting of the Committee of Ministers $16^{\text {th }}$ of June 2010, when an updated version of the Code of Sport Ethics recommended to Member States was adopted and the need for coordination between governments and sports organizations was emphasized. This monograph presents the efforts of many scientists from different fields (philosophy, history, sociology, sports sciences, biology, etc.) to analyze issues of sports ethics. The content of the monograph is presented through the following topics: Chapter 1 Ethics in sports: historical and philosophical context; Chapter 2 - New Challenges of Ethics in Sport.

Ягодин ${ }^{11}$ discusses the essence of a relatively young science - sports ethics in his book Fundamentals of Sports Ethics. In that sense, from the philosophical and pedagogical point of view, concepts and social phenomena such as: ethics,

9 Warren Fraleigh, Right Actions in Sport, Ethics for Contestants, (Champaign, Illinois: Human Kinetics, 1984).

10 D., Bodin \& G. Sempé, Ethics and sport in Europe. (Council of Europe, 2011).

11 В. В. Ягодин, Основы спортивной этики. (Екатеринбург: Изд-воУрал. ун-та, 2016). 
morality, culture, sports, sports culture, Olympism, Olympic culture, Olympic movement, moral education were considered. The book is intended for experts working in the field of physical culture. He views sports ethics through five main thematic units, which he elaborates through certain sub-topics: ethics as a philosophical science (ethics - the science of morality; a short history of ethics, the morality of modern society); contemporary sport as a social phenomenon (functions of contemporary sport, dispute in the life of modern society, contemporary tendencies in the development of sport); the concept of sports ethics (sports and Olympic culture, what is sports ethics? Ethics of professional sports, sports behavior, the "fair play" movement - the quintessence of sports ethics); fan movement (from the history of the fan movement; football fan groups); educational aspect of sports ethics (concept of moral education, sports education, folk culture and sports education).

The monograph, Sports Ethics, is important for development of sports ethics as a discipline. The monograph is a manifesto for the 21st century, written by Milan Hosta. The author is dedicated to research and development of ethics through the prism of sports and recreation. The book consists of nine chapters arranged in a logical and didactic order. In the monograph, the author deals with ethics in top sports and recreation and says that in the ethics of sports there is a tradition of each sports subculture, which is presented as an authority, which affects the difference between acceptable and unacceptable. According to the author, passion, bestiality and instincts that manage sports at the highest level, by definition, are beyond control and the ability to tame. In the chapter on the ethics of recreation, Hosta says that if we attribute the logic of the maximum to top sports, we attribute the logic of the right measure to recreation. Therefore, the ethics with which one enters the field of recreation cannot be different, but the ethics of the right measure, only that the "relationship" is sharpened, which sharpens the validity of ethics. Hosta also states that the difference between the ethics of sports and the ethics of recreation is not often discussed. When drawing a parallel between these two parts of physical culture, the author states that the athlete always knows what he wants. The path to the top is not important, that path is known and limited by the rules of the game, but it is important to reach the top and that is why hesitation is not allowed. The athlete gives his best and sometimes goes beyond his limits, and in that area of excess, comfort turns into pain, and the athlete still has to persevere in competition. This is a special condition that is qualitatively different from that in recreation.

Robert L. Simon ${ }^{12}$ considers several ethical issues related to physical culture in his book Fair Play: The Ethics of Sport through seven units: Introduction - ethics of

12 Роберт. Л. Сајмон, Фер - плеј етика спорта. (Београд: Службени гласник, 2006). 
sports; Competition, a common need for excellence; Sportsmanship; Doping and violence; Girls and boys, men and women; Sports University; Commercialization of sports. Simon discusses and analyzes Vince Lombardi's position that victory is not the most important thing, but the only thing. He concludes that the issues that are crucial for the moral evaluation of sports arise from this attitude. He is of the opinion that coaches and parents attach too much importance to victory and that competitive success is often overemphasized, especially at the level of younger categories. The author states in one part that if competition in sports is viewed as a common search for excellence, then cheating, disrespect for the game or bad sports behavior violate the ethics of sports competition (Simon, 2006, p. 98). The author views doping as one of the biggest problems of modern sport, and his position is that where doping leads to a better game, it is not the competitor who deserves to win. Simon also deals with issues of gender equality in the field of sports. According to him, the sexes are different, but equal, because if that were not the case, women would be practically absent from sports competitions of the highest level. He further considers the ethical issue of enrolling talented athletes in recognized faculties just to compete in a particular sport. In support of this claim, he states that at the University of Oklahoma, in the period of four years, no student who played in the basketball team of the faculty completed his studies. The negative impact of money is also emphasized, because players are seen as a commodity, and as a result, they are treated less as persons and more as a product. As a final comment, he points out the positive effect of commercialization, which refers to the fact that sports monitoring is available to a large number of people across our planet.

Sigmund Loland ${ }^{\mathbf{1 3}}$ in his book Fair Play in Sport: A Moral Norm System, offers a comprehensive display of fair play in sports. Its aim is to provide a synthesis between traditional moral principles and their practical application. Topics within this book include the notions of fairness, justice and equality, what constitutes "good" competition, and the value of sport as an activity in itself. Some of the chapters that present the topic of the book are: Sport Competitions; Fair Play Background and Definitions; Basis for A Rational Morality; Establishing a Hypothetical Ethical Contract Situation; Specifying the Contract Situation; Good Sport Competitions, etc. This book is a valuable contribution to the consideration of the topic of fair play in sports.

Ronald Renson ${ }^{14}$ in his paper Fair Play: Its Origins And Meanings In Sport And Society gives the genesis of the origin of this concept. The concept of fair play is a world-famous and understandable concept that has its origins in sports. Fair play

\footnotetext{
13 S. Loland, Fair Play in Sport: A Moral Norm System. (London and New York: Routledge, 2002).

14 Ronald Renson, Fair Play: Its Origins And Meanings In Sport And Society. Kinesiology, 41(1) (2009): 5-18.
} 
is not only an essential element of sports, but it has also become a general philosophy of respecting the rules and other people in sports competitions. The origin of this term is connected to England and the beginnings of modern sports. This author points out that he looks very positively at the future of fair play in the educational environment and in the context of recreation. However, he points out that he is not so optimistic when it comes to professional sports, where everything is viewed from the economic aspect. On this occasion, his following position should be emphasized: "serious sport has not been taken seriously enough for too long." In his opinion, fair play is one of the most important contributions that sport has made to modern ethics. Without fair play, sports, as well as other competitive activities, become a matter of winning at all costs.

A significant contribution to understanding the problems in this area was provided by Миливоје Матић ${ }^{15}$ with his paper Review of the ethical values of physical movement/exercise. Матић points out that physical movements-exercise must develop and improve spiritual dimensions in human development, in parallel with physical measures, they will not spontaneously merge into a developed and healthy body as an automatic technical-mechanical-physiological consequence of the act of physical exercise, but must be systematically discussed. According to the author, one can talk about the ethical values of bodily movement only when they reach the level of mental and social maturity, found his place in society and if it is realized through various social interactions. Ethical values of bodily movement appear only in an autonomous person who works on their perfection with bodily movement-exercise and does it for themselves. Матић concludes that the binding of the moral dimensions of physical culture, which stem only from the direct practice of competition, the winner's fault, for respecting the loser, for disrespecting the rules of the game and competition, speaks of not considering the basic moral unit in physical culture.

Drago Tomić's ethics in sports is focused on his efforts to expose false ethical judgments in sports and that the ethics of athlete behavior be in within valid norms of behavior. The paper is divided into two parts. The duality of ethics in a sport in which relationships are based on humanistic ethics on the one hand, and irrational authority based on differences in values and power over athlete, is discussed in the first part of the paper. The second part of the paper deals with athletes as personalities, because they are unique beings in their own specific way, but they also have many similarities in life situations and ways of solving existence. The personality of an athlete, like any other person, can always be influenced, both positive and negative.

15 М. Матић, Оглед о етичким вредностима телесног кретања-вежбања. Физичка култура, 36(4), (1982): $293-300$. 
Јанко Лескошек ${ }^{16}$ dealt with ethical issues, but only in the field of sports. His paper Socio-ethical aspects of sports deals with negative, deviant phenomena of sports and measures that should be taken to eliminate or at least reduce them. Leskošek states that: there are phenomena that are reflected in the wrong evaluation of sports, commercialism, club concerns, egoistic, localistic and chauvinistic tendencies, unsportsmanlike atmosphere in clubs and among clubs, referees and coaches, winning, bribing, buying players, glorifying other sports. Leskošek concludes his work by stating that deviations in sports are inadequate to the process of humanization and today are exclusively related to sports, but to a significant extent also indicate the morality of society. At the same time, these deviations have their repercussions, negatively affecting the morale of athletes and other people. Negative phenomena in sports will not be eliminated or reduced unless a decisive and uncompromising fight is waged for their systematic elimination. The deviation will be less if, in addition to already professional issues, attention is paid to the moral education and re-education of athletes and other factors related to sports.

Марковић и Бокан conducted a survey on a sample of candidates enrolled at the Faculty of Sports and Physical Education at the University of Belgrade. The aim of this research was to use a specially designed questionnaire to examine the attitudes of candidates for enrollment at the FSFV in Belgrade on their ethical views and applicability in physical culture. In this paper, the authors used a specially constructed questionnaire called "Ethics and Sports", which was taken from the research of Brkljačić-Žagrović et al. The authors end the paper by stating that the data obtained are an important indicator of the relationship between ethical values and engaging in certain motor activities. They point out that the research should continue in the next generations, because this was only the first on the sample of FSFV candidates in Belgrade. The questionnaire showed satisfactory characteristics, but research on improving the structure of the question must continue.

Морана Бркљачић in Ethics and Sport ${ }^{17}$ made a research on sports ethics from a medical point of view. The ethics of sports doctors is greatly tempted when an athlete is injured, due to the desire of club management, competition organizers, coaches or even an injured athlete to continue the competition at any cost. The decision to return the athlete to the field has not been sufficiently recovered by the medical etiquette, because it must be guided exclusively by medical motives. Brkljacic concludes that athletes, in their desire to be the best, to bring profit to their club, community and themselves, sometimes do so at the cost of their own health and despite the advice of doctors. The same author and her associates

\footnotetext{
${ }^{16}$ Јанко Лескошек, Друштвено-етички аспекти спорта. Физичка култура,35(1), (1981):12-17.

${ }^{17}$ Morana Brkljačić, Etika i sport. Medicina Fluminensis, 43(3) (2007): 230-233.
} 
conducted a quantitative research in 2011. on a sample of athletes and recreational athletes in order to determine the attitudes of athletes and recreational athletes towards the ethics of today's sport. This questionnaire was anonymous and consisted of two parts. The first part referred to basic data, such as age, gender and type of activity they are engaged in, and the second part included ten questions related to moral values in physical culture. As a conclusion of this paper, the authors state that it is necessary to introduce a subject within higher education institutions that educate staff for work in the field of physical culture when considering ethical issues ${ }^{18}$.

\section{DISCUSSION}

Sports ethics can be viewed in two ways: in everyday (common) and scientific understanding. These two views are interconnected because they have a common element - morality as a necessary quality of positive attitudes of participants in sports. Sports ethics in everyday understanding represents unwritten norms of behavior of participants in sports. An honest and correct relationship between participants in sports is the basis of morality in sports. This implies justice, principle, respect for rules, honesty before others and before oneself. The opposite of this is cheating, lying, hypocrisy, theft. The attitude towards the opponent is an indicator of the athlete's upbringing. This also applies to coaches and other participants in sports. True ethics is related to value concepts such as: responsibility, sociability, collectivism, honor and dignity, justice and selflessness. In the scientific sense, sports ethics is viewed as part of general ethics and it studies and analyzes morality as a set of norms, values and ideals that regulate the behavior of people who participate in sports and represent important parts of sports culture.

For consideration in this paper, the scientific approach to understanding sports ethics is primarily important, with the understanding that the everyday (usual) one is certainly present in a certain way in the scientific one as well. In the aforementioned monographs and scientific papers, the authors viewed sports ethics through various aspects to a greater or lesser extent. Monographs dealing with sports ethics are mostly composed as collections of individual works by various authors who have dealt with this topic and which the editors of the collection have linked in a systematic and appropriate way into various broader thematic units. These wholes are presented as chapters or parts in monographs.

18 Morana Brkljačić Žagrović, S. Brkljačić Beg, M. Mavrinac, Sorta-Bilajac Turina, I. Bunjevac \& T. Čengić, Može li suvremeni sport bez svoje etike? - potreba za sustavnom edukacijom. JAHR, 2(3), (2011): 93-110. 
The topics with which they considered the content of the term sports ethics are quite broad and different, but they also have some common elements.

In most monographs there are papers dealing with the interpretation of the concept of ethics in general and sports ethics, the relationship between ethics and philosophy and ethics and other areas of life and about sport itself (McNamee \& Perry, 1998 - Ethics and sport - the contribution of philosophy; McNamee, 2010 Ethics and adventure activities; Bodin \& Sempé, 2011 - Ethics in sport: historical and philosophical context; Jagodin, 2016 - ethics as a philosophical science; contemporary sport as a social phenomenon; the concept of sports ethics; Simon, 2006 - Introduction - ethics of sport; Matić, 1982 - Review of the ethical values of physical movement/exercise; Tomić, 1982 - Ethics in sports).

A fair play is an element that appears to be generically related and defining in all presented papers in monographs as an essential concept on which most ethical requirements in sport are based (Morgan, 2001 - competition and fair play: considerations of victory, cheating and victories at all costs; McNamee \& Perry, 1998 - Fair play and sporting behavior; Boxill, 2003 - Sport and competition; Loland, 2002 - Fair play sports competitions: moral norms system; Renson, 2009 Fair play: its origins and meanings in sport and society). As an important part of sports ethics were considered:

- rules in sports and attitudes towards them (Morgan, 2001 intentional violations of rules; McNamee, 2010 - Fair competition: The Roots of Sports Ethics: Games, Play, Sports; Loland, 2002 Sports competitions: rules, goals and social logic),

- moral values (virtues and vices), education and upbringing in and about sport (Morgan, 2001 - metaethical considerations of sport; McNamee \& Perry, 1998 - Ethics, physical education and sports training; McNamee, 2010 - Ethical development in sport and through care; virtues and vices; Boxill, 2003 - Sports and education; Sports and sports behavior; Models of sports and roles; Bodin \& Sempé, 2011 - New challenges of ethics in sports; Jagodin, 2016 - educational aspect of sports ethics; Simon, 2006 - Sports behavior; Loland, 2002 - Moral point of view, Correct sports competitions: correctness, Good sports competitions: game; Leskošek, 1981- Socio-ethical aspects of sports; Brkljačić, 2007 Ethics and sports, Marković and Bokan, 2014).

Some monographs and papers also researched the genesis of ethics in general and sports ethics (McNamee, 2010 - The Roots of Sports Ethics: Games, Play, Sports).

The following are considered as negative elements that violate the principles and code of sports ethics: 
- cheating and breaking the rules (McNamee \& Perry,1998 Contemporary ethical issues in sports), use of doping, drugs, pharmacological agents and genetic modification (Morgan, 2001 human boundaries: doping and genetic advancement in sport; McNamee, 2010 - Doping, genetic modification and ethics of improvement; Boxill, 2003 - Sport and drugs; Simon, 2006 - Doping and violence),

- violence (Morgan, 2001 - Selected content from the social ethics of sport: violence, exploitation, race, viewership and disability; (McNamee \& Perry, 1998 - Contemporary ethical issues in sport; Boxill, 2003 - Sport and violence; Simon, 2006 - Doping and violence),

- commercialism, corruption and exploitation of various types (Morgan, 2001 - Selected content from the social ethics of sport: violence, exploitation, race, ratings and disability; McNamee, 2010 Commercialism, corruption, exploitation in sport; Simon, 2006 Commercialization of sport),

- racial and gender inequality and disability inequality (Morgan, 2001 - gender and gender equality in sport; Morgan, 2001 Selected content from the social ethics of sport: violence, exploitation, race, viewership and disability; Boxill, 2003 - Sport and gender ; Sports and Racial Issues; Simon, 2006 - Girls and Boys, Men and Women),

- fan fanaticism (Jagodin, 2016 - Fan movement).

\section{CONCLUSION}

People's behavior is largely based on moral principles that reflect the moral side of their personality. Based on the relationship between the subjects of sports activity, in principle, there should be general moral principles: honesty, justice, humanity, respect, honesty, etc. Since ethics, in its essence, should regulate the relations between the subjects of activity, then sports ethics, requires above all, that the subjects of sports activity create, maintain and strengthen sports relations (sports behavior). It requires a relationship of respect for everyone with whom you come into direct or indirect contact in a certain way.

Ethical topics are present in theoretical considerations of sport continuously during its development. Sports ethics deals with considerations in general in sports as a social activity, but also in individual sports, encompassing behaviors, procedures, attitudes, customs, etc. A great influence on the development of sports ethics was the publication For Virtue - a study of moral theory by Alastair McIntyre, whose ideas were considered and applied by various authors in their 
views on sports phenomena, which led to the development of fair play theory, ie consideration of (undesirable) characteristics. Within the present research, an overview of theoretical, research, and professional papers is given. The review of papers gave insight into the connections between ethics and sports and it gave a certain contribution to the understanding of this issue. Thematic areas and phenomena discussed are the concept of ethics and sports ethics, the relationship between sports ethics and other areas of life, fair play, rules in sports and attitudes towards them, moral values and education in sports, the genesis of sports ethics, violation of sports ethics by various negative behaviors (cheating and breaking rules; use of doping, drugs, pharmacological agents and genetic modification; violence; commercialism, corruption and exploitation of various types; racial and gender inequality and disability inequality, fan fanaticism). A significant part of the consideration of sports ethics refers to various negative phenomena in sports that contribute to the violation of moral principles and that are socially undesirable. The fact is that such phenomena are more and more present in sports and that they represent a great social problem, so it is important that they constantly stand out, but it is even more important to work on their prevention by appropriate action of all subjects of society, locally and globally.

Sport is a part of the social sphere, where it is necessary to have a balance between social regulation, control, and personal choice. Only with the joint action of the state and the institution of civil society, business, and individuals themselves, it is possible to overcome the existing problems and thus ensure the future health of the state and the comprehensive development of people.

Ethical topics are present in theoretical considerations of sport continuously during its development. Sports ethics deals with considerations in general in sports as a social activity, but also in individual sports, encompassing behaviors, procedures, attitudes, customs, etc. A great influence on the development of sports ethics was the publication For Virtue - a study of moral theory by Alastair McIntyre, whose ideas were considered and applied by various authors in their views on sports phenomena, which led to the development of fair play theory, ie consideration of (undesirable) characteristics. Within the present research, an overview of theoretical, research, and professional papers is given. The review of papers gave insight into the connections between ethics and sports and it gave a certain contribution to the understanding of this issue. Thematic areas and phenomena discussed are the concept of ethics and sports ethics, the relationship between sports ethics and other areas of life, fair play, rules in sports and attitudes towards them, moral values and education in sports, the genesis of sports ethics, violation of sports ethics by various negative behaviors (cheating and breaking rules; use of doping, drugs, pharmacological agents and genetic modification; violence; commercialism, corruption and exploitation of various types; racial and gender inequality and disability inequality, fan fanaticism). A significant part of the consideration of sports ethics refers to various negative 
phenomena in sports that contribute to the violation of moral principles and that are socially undesirable. The fact is that such phenomena are more and more present in sports and that they represent a great social problem, so it is important that they constantly stand out, but it is even more important to work on their prevention by appropriate action of all subjects of society, locally and globally.

Sport is a part of the social sphere, where it is necessary to have a balance between social regulation, control, and personal choice. Only with the joint action of the state and the institution of civil society, business, and individuals themselves, it is possible to overcome the existing problems and thus ensure the future health of the state and the comprehensive development of people.

\section{REFERENCES}

1. Brkljačić, Morana. Etika i sport. Medicina Fluminensis, 43(3) (2007): 230-233.

2. Brkljačić, Žagrović, Morana, Brkljačić Beg, S., Mavrinac, M., Sorta-Bilajac Turina, Bunjevac,I., \& Čengić, T. Može li suvremeni sport bez svoje etike? - potreba za sustavnom edukacijom. JAHR, 2(3), (2011): 93-110.

3. Bodin, D., \& Sempé, G.. Ethics and sport in Europe. Council of Europe, 2011.

4. Boxill, J. (ed), Sports Ethics, an Anthology, Blackwell Publishing, Malden, 2003.

5. Живановић, Ненад. Апологија физичког вежбања. Ниш: Паноптикум, 2011.

6. Живановић, Ненад, Петар Павловић, Верољуб Станковић и Небојша Ранђеловић. Теорија физичке културе. Ниш: Паноптикум, 2011.

7. Despotović, Ljubiša. One-dimensional sport spiritual crisis as a cause of degrading sport to a one dimesional phenomenon. Physical education and sport through the centuries, 5(2) (2018): 68-77

8. Kozarčanin, Azra. Etika u sportu (Ethics in sport), Sport Science, International Scientific Journal of Kinesiology 1(1) (2008)

9. Кузнецов, П.К. Гуманистические ценности массового спорта как средство формирования всесторонне развитой личности // Известия Российского государственного педагогического университета им. Герцена. СПб. г. (2012)

10. Лескошек, Јанко. Друштвено-етички аспекти спорта. Физичка култура,35(1), (1981):12-17.

11. Loland, S. Fair Play in Sport: A Moral Norm System. London and New York: Routledge, 2002.

12. McNamee, M. J. and Parry, S. J. (eds) Ethics and Sport, London: Routledge (1998)

13. McNamee, Mike J. The Ethics of Sports: A Reader, London: Routledge (2010)

14. MacIntyre, A. AfterVirtue: AStudy in Moral heory, University of Notre Dame Press, 1981.

15. Матић, Миловоје. Оглед о етичким вредностима телесног кретања-вежбања. Физичка култура, 36(4), (1982): 293 - 300

16. Morgan, W. J., Meier, K. V. and Schneider, A. J. (eds) Ethics in Sport, Champaign, Illinois: Human Kinetics (2001)

17. Platon. Država. Beograd; BIGZ, 1997 
18. Renson, Ronald. Fair Play: Its Origins And Meanings In Sport And Society.

Kinesiology,41(1), Belgium: Faculty of Kinesiology and Rehabilitation Sciences, (2009): 5-18.

19. Сајмон, Роберт. Л. Фер - плеј, етика спорта. Београд: Службени гласник, 2006.

20. Томић, Драго. Етика у спорту. Физичка култура, 36(1), (1982): 82-84.

21. Fraleigh, Warren. Right Actions in Sport, Ethics for Contestants, Champaign, Illinois: Human Kinetics, 1984.

22. Хоста, Милан. Етика шпорта - манифест за 21 столетје. Љубљана: Факултет за шпорт, 2007.

23. Ягодин, В. В. Основы спортивной этики. Екатеринбург: Изд-воУрал. ун-та, 2016.

\title{
ЭТИКА И СПОРТ, ЭТИКА В СПОРТЕ, СПОРТИВНАЯ ЭТИКА - АСПЕКТЫ, РАССМОТРЕННЫЕ РАЗНЫМИ АВТОРАМИ
}

\begin{abstract}
АННОТАЦИЯ
Вопросы этики сегодня актуальны везде, где существует конкуренция за прибыль. Современный зарегистрированный спорт является социальной деятельностью и, следовательно, одной из сфер, в которой присутствует вышеупомянутое явление.

Спортивная этика как термин в повседневной жизни понимается как неписаные правила поведения людей в спорте, и в этом смысле она исходит из предположения о честных отношениях во всех сферах спорта. Честность одна из основных человеческих ценностей, характеристика, отражающая добродетельность, принципиальность, верность обязательствам, порядочность. Противоположность этому - ложь, обман, лицемерие.

Соблюдение этических правил (норм) усиливает моральное влияние спорта и ответственность всех участников спорта за свое поведение, а также, благодаря огромной привлекательности спорта для молодежи, способствует улучшению морального климата в молодежной среде.

Практические исследования и теоретические работы об обусловленности и связи между этикой и спортом существуют, но они в определенной степени немногочисленны.

В статье рассматривается феномен спорта и его связь с этикой, делается обзор теоретических, исследовательских и профессиональных работ, излагается суть отдельных работ, важных для изучения данного вопроса. В них определенным образом рассматривается связь этики и спорта.
\end{abstract}

Ключевые слова: спорт, этика, спортивная этика 